\title{
Current status and achievements of Polish transfusion medicine
}

\author{
Jolanta Antoniewicz-Papis ${ }^{1 *}$, Ewa Brojer ${ }^{2}$, Jadwiga Fabijańska-Mitek ${ }^{3}$, Agnieszka Gierszon², \\ Piotr Grabarczyk ${ }^{4}$, Katarzyna Guz ${ }^{2}$, Aleksandra Kalińska ${ }^{4}$, Aneta Kopacz ${ }^{4}$, Jolanta Korsak ${ }^{5}$, \\ Elżbieta Lachert ${ }^{1}$, Magdalena Łętowska ${ }^{1}$, Patrycja Łopacz ${ }^{2}$, Bogumiła Michalewska ${ }^{2}$, \\ Agata Mikołowska ${ }^{1}$, Jacek Nowak ${ }^{6}$, Adam Olszewski ${ }^{7}$, Agnieszka Orzińska ${ }^{2}$, \\ Monika Pelc-Kłopotowska ${ }^{2}$, Ryszard Pogłód ${ }^{1}$, Piotr Radziwon ${ }^{8}$, Aleksandra Rosiek ${ }^{1}$, \\ Anna Stachurska-Skrodzka ${ }^{3}$, Ewa Sulkowska ${ }^{4}$, Zbigniew M. Szczepiorkowski ${ }^{1,9}$, \\ Małgorzata Uhrynowska ${ }^{2}$, Beata Uszyńska-Kałuża ${ }^{10}$, Beata Wojciechowska ${ }^{2}$ \\ ${ }^{1}$ Department of Transfusion Medicine, Institute of Hematology and Transfusion Medicine, Warsaw, Poland \\ ${ }^{2}$ Department of Immunohematology, Institute of Hematology and Transfusion Medicine, Warsaw, Poland \\ ${ }^{3}$ Centre of Postgraduate Medical Education, Warsaw, Poland \\ ${ }^{4}$ Department of Virology, Institute of Hematology and Transfusion Medicine, Warsaw, Poland \\ ${ }^{5}$ Department of Transfusion Medicine, Military Institute of Medicine, Warsaw, Poland \\ ${ }^{6}$ Department of Immunogenetics, Institute of Hematology and Transfusion Medicine, Warsaw, Poland \\ ${ }^{7}$ Military Blood Transfusion Center, Warsaw, Poland
}

${ }^{8}$ Regional Blood Transfusion Center, Białystok, Poland, Department of Hematology, Medical University of Białystok, Poland

${ }^{9}$ Dartmouth-Hitchcock Medical Center, Lebanon, NH, USA

${ }^{10}$ Blood Transfusion Center of Ministry of Internal Affairs and Administration, Warsaw, Poland

\section{Abstract}

Transfusion of blood and blood components is one of the widely used medical procedures. The responsibility for provision of blood and blood components lies with Polish blood transfusion centers (CKiK) substantively supervised by the Institute of Hematology and Transfusion Medicine. Hospital based blood banks, hospital wards, immunohematology laboratories are supervised by CKiK. Every year approximately 600 thousand people donate blood, more than 75\% of which are regular donors. The annual number of donations is maintained at a constant level of about 1.3 million.

The aim of this position paper is to present the current status, achievements and advancement in collection, preparation and testing procedures and methods used to obtain the best possible quality blood components dedicated for clinical use. The aim is also to show the structure of blood transfusion service in Poland. Collaboration of all organizational units involved in transfusion medicine is crucial for providing high quality health care for patients.

Polish transfusiologists and blood transfusion officers have largely contributed to transfusion science with numerous publications and significant research work. The implementation of novel methods and ongoing research positions Polish blood transfusion service among those of highly developed countries.

Key words: Transfusion Section of Polish Society of Hematologists and Transfusiologists, transfusion medicine

Acta Haematologica Polonica 2021; 52, 3: 147-162

*Address for correspondence: Jolanta Antoniewicz-Papis, Department of Transfusion Medicine, Institute of Hematology and Transfusion Medicine, Indiry Gandhi 14, 02-776 Warsaw, Poland, phone: +48 223496 381, e-mail: jpapis@ihit.waw.pl

Received: 9.04.2021
PTHiT Copyright (c) 2021 The Polish Society of Haematologists and Transfusiologists, Insitute of Haematology and Transfusion Medicine. All rights reserved.




\section{Introduction}

Transfusion of blood and blood components is one of the commonly used medical procedures particularly important for patients with hematological disorders who require multiple transfusions and often specially prepared blood components. Therefore close collaboration between hematology and transfusion medicine is not only important but required. Also in other medical specialties the supportive role of blood component transfusion has been steadily growing while ongoing research in transfusion medicine contributes to improved therapeutic outcomes.

To emphasize the significant role of transfusion medicine not only for hematology, in 1975 the Polish Society of Hematologists changed its name to Polish Society of Hematologists and Transfusiologists (PTHiT). Professor Halina Seyfried was the first Chairman of the Transfusion Section and held the post until 1999 followed by professor Magdalena Łętowska (1999-2010), professor Ewa Brojer (2010-2019) and dr. hab. Jolanta Antoniewicz-Papis (since 2019).

The sequence of national consultants in clinical transfusion was as follows: prof. Halina Seyfried (until 1999), dr hab. Jan Sabliński (1999-2001), prof. Magdalena Łętowska (2001-2006), prof. Piotr Radziwon (2006-2008), prof. Ryszard Pogłód (2008-2015), dr hab. Paweł Łaguna (2015-2016). Since 2016 the function of national consultant has been performed by prof. Piotr Radziwon. The transfusion medicine consultants for individual provinces are: Jadwiga Hołojda, PhD (Dolnośląskie and Lubuskie province), Katarzyna Błaszkiewicz, PhD (Lubelskie province), Karolina Trojan-Borczyńska (Łódzkie province), Jolanta Raś (Małopolskie province), Monika Grzegorek (Mazowieckie province), Alicja Wysocka (Podkarpackie province), Dariusz Średziński (Podlaskie province), Izabela Trepka (Śląskie province), Zdzisława Sitarz-Żelazna (Świętokrzyskie province), Agnieszka Łaba (Wielkopolskie province), Ewa Kłosińska (Zachodniopomorskie province).

It is worth noting that apart from its basic activities the Transfusion Section of PTHiT is also involved in organizing and conducting training activities for doctors and laboratory diagnosticians involved in blood therapy.

\section{Organization of the Blood Transfusion Service in Poland}

The structure and tasks of the public Blood Transfusion Service (BTS) in Poland are regulated by the Polish Blood Transfusion Act of $22^{\text {nd }}$ August 1997 [1]. The activity of Polish BTS is based on 21 regional blood transfusion centers [Regionalne Centra Krwiodawstwa i Krwiolecznictwa (RCKiK)] with their local collection sites (129), the Military Blood Transfusion Center [Wojskowe Centrum Krwiodawstwa i Krwiolecznictwa (WCKiK)] with local military blood donation stations [Terenowa Stacja (TS)] and the Blood
Transfusion Center of the Ministry of Internal Affairs and Administration [Centrum Krwiodawstwa i Krwiolecznictwa Ministerstwa Spraw Wewnętrznych i Administracji (CKiK MSWiA)]. All blood transfusion centers (CKiK) are accredited by the Minister of Health to perform their activities in accordance with the Polish Blood Transfusion Act and are supervised by the Institute of Hematology and Transfusion Medicine [Instytut Hematologii i Transfuzjologii (IHiT)]. Blood is collected in headquarters of all CKiK as well as in local collection sites (129) and 7 TSs of WCKiK. Screening for infectious agents as well as immunohematological tests and blood component preparation are performed in the headquarter laboratories of CKiK. The number of CKiK has been unchanged for many years now while the number of local collection sites has been decreasing steadily since 1997 with 453 local collection sites discontinuing their activities prior to 2019. At the same time, the number of mobile collections has been growing steadily achieving approximately 13,000 collections annually.

The Minister of Health supervises the public BTS. Apart from the Minister the role of competent authorities [2] for blood is also performed by the National Blood Center (NCK) as well as the IHiT with their respective activities and responsibilities. The Main Pharmaceutical Inspectorate is also engaged in BTS activity as the organ inspecting CKiK as providers of raw material for production of medical products.

The hospital-based blood banks and immunohematology laboratories do not belong to the public BTS and are directly responsible for supplying blood/blood components to in- and outpatients in their respective facilities.

The consultants in transfusion medicine also participate in the activities of BTS. The Military Blood Transfusion Center and the Center of the Ministry of Internal Affairs and Administration support activities of respective Ministries according to the recommendations.

\section{Role of the Military Blood Transfusion Service} The Military Blood Transfusion Center (WCKiK) was established in 2005 and is the successor of military blood transfusion service (MBTS). It holds the accreditation of the Ministry of Health. The MBTS was established by the Order of the Minister of National Defense No. 6 issued on January 8, 1961. Initially MBTS consisted of military blood donation stations located on the premises of military hospitals (MHs). Currently WCKiK is independent from MHs and is supervised by the Ministry of Defence. WCKiK consist of headquarters (HQ) with a Medical Team located in Warsaw and 7 TSs (in Bydgoszcz, Ełk, Gdańsk, Lublin, Kraków, Szczecin, Wrocław). Annually, about 30,000 units of whole blood and blood components are collected (including units collected by apheresis). TSs supplies blood and blood components to military hospitals (and civilian hospitals if necessary) as well as to military medical units performing medical duties outside the country. WCKiK 
actively cooperates with the blood transfusion services of other North Atlantic Treaty Organization (NATO) countries and participates in the development and implementation of methods/procedures related to the use of blood and blood components for military purposes. The major achievements of the WCKiK include implementation of all modern techniques previously used in the civilian blood transfusion service as well as methods dedicated mainly to the military blood transfusion service such as: leukoreduction of red blood cell concentrates (RBCCs) using in-line filtration, application of the transcription mediated assay (TMA) for human immunodeficiency virus (HIV), hepatitis B virus (HBV), hepatitis $\mathrm{C}$ virus (HCV) detection, cryopreservation of leukoreduced RBCCs, rapid infuser-based fresh whole blood transfusion and Walking Blood Bank procedures for patients experiencing a hemorrhagic shock [3-5].

\section{Role of the the Blood Transfusion}

Center of the Ministry of Internal Affairs

and Administration (CKiK MSWiA)

The Blood Transfusion Center of the Ministry of Internal Affairs and Administration (CKiK MSWiA) was established in July 2004 and its activity began in September 2004.

Just like all other CKiKs, the CKiK MSWiA has the accreditation of the Ministry of Health for collection and preparation of blood/blood components and annually collects blood and blood components from approximately 10,000 donors.

The specific tasks of CKiK MSWiA involve medical safeguard of the defense responsibilities of the Minister of Internal Affairs.

In realization of its duties CKiK MSWiA cooperates with medical establishments founded by the Minister of Internal Affairs.

CKiK MSWiA participates in many scientific and research projects and - among others - collaborates with the National Academy of Sciences as well as medical universities.

CKiK MSWiA supervises the organization of blood transfusion in hospitals founded by the Minister of the Internal Affairs and Administration (currently 18 located throughout the country).

\section{The role of the National Consultant in Transfusion Medicine}

The National Consultant in Transfusion Medicine (NCTM) is appointed by the Minister of Health with the duties, rights and competences regulated by the dedicated act of law [6]. The NCTM forwards opinions, offers advice and provides expert knowledge for the Minister of Health, the National Blood Centre and National Health Fund. The person appointed NCTM is also the president of the National Blood Transfusion Council. The NCTM exercises supervision over the professional proficiency and specialization of physicians, nurses, and laboratory staff in the field of transfusion medicine, offers advice to the Medical Examinations Centre as well as oversees and heads state examinations in clinical and laboratory transfusion medicine. The NCTM gives opinions on drafts of legal acts and suggests actions for better compliance of practice with recommendations. The NCTM also has a supportive role in realisation of National Health Programme and other health policy projects. The NCTM prepares expert opinions on diagnostic and therapeutic procedures with impact on transfusion of blood/ /blood components as well as on medical equipment and products. On behalf of the Minister of Health the NCTM visits health service establishments: blood centres, hospitals, laboratories and blood banks

\section{Role of national consultant in transfusion} medicine for the sector of national defence As result of the geo-political order Poland is situated at the front zone of NATO and the European Union. The nature of the future armed conflict enforces new substantive and logistic solutions as regards medical safeguard and health with special emphasis on supply of blood and blood components. These tasks differ from those of civilian blood transfusion services. The national consultant is the member of expert and advisory committee which supports the Director of the Military Health Service of the Ministry of National Defense. The consultant's specific tasks include supervision over the implementation and strengthening of vocational training, monitoring of workforce requirements in transfusion medicine as well as consulting complex clinical cases and organization challenges. The special role of the defense consultant lies in the planning and organization of safeguard measures for military troops as well as development of procedures specific for combat situations. The most important role of the national consultant is establishing transfusion medicine strategies for the military personnel.

Since 2005 the national consultant has been in collaboration with the Medical Blood Advisory Team (MBAT) team of NATO experts (now Blood Panel), resulting in European recommendations in military blood service practice - especially for multi-site injury cases. National consultant in transfusion medicine also participated in the implementation of STANAG $29395^{\text {th }}$ edition - opinion for the NATO Standardization Agency, cooperated in creation of STANAG 2939 $6^{\text {th }}$ edition and STANAG 2068 (Emergency War Surgery Handbook) as well as development of team opinion regarding the use of tranexamic acid in cases of massive haemorrhage $[7,8]$. The essential role of the consultant is participation in discussions on development of MBAT strategy.

\section{Statistical data for donors and donations; Polish register \\ Polish donors of blood and blood components In the years 2017-2019 a total of 2,160,751 persons report- ed to donate blood and blood components at the Polish BTS}


(719809, 721315,719627 respectively). Eligible for donation were 1841680 (85\%) of those willing to donate (612 531 in 2017, 614570 in 2018; 614579 in 2019), 512290 (28\%) of whom were women (171 305 in 2017, 171164 in 2018, 169821 in 2019) and 1329390 (72\%) were men (441 226 in 2017, 443406 in 2018, 444758 in 2019). Voluntary unremunerated donors were 99.9\% (1 839 522).

The majority of donors found eligible for donation of blood/blood components were regular donors - above $75 \%$, while first time donors were almost $25 \%$. Most numerous were the 25-44 age group (1 045 114, 57\%), followed by the 18-24 age group (558 570, 30\%) and the 45-65 age group (23 106, 13\%). The least numerous donor groups were age groups below $18(151,<0.1 \%)$ and above 65 (739, <0.1\%).

Donations were not collected from $15 \%$ of persons who declared willingness to donate blood/blood components. Almost $54 \%$ of them were women and slightly above $46 \%$ were men.

\section{Donations of blood and blood components}

For many years now, the most common component collected in Polish BTS was whole blood (WB), while the least frequently collected components were apheresis red blood cells (RBCsAph) and granulocyte concentrates (GCs).

The annual number of WB donations has been maintained at a constant level of about 1.2 million for the last several years. In 2017-2019, a total of 3676563 units of WB were collected (1 210706 in 2017, 1223845 in 2018, 1242012 in 2019) almost 99,9\% of which were collected from voluntary unremunerated donors (3 673 140; 1209423 in 2017, 1222752 in 2018, 1240965 in 2019) including over 78\% collected from men ( 2867305 ; 951297 in 2017, 960969 in 2018, 955039 in 2019) and almost 22\% from women (805 835; 258126 in 2017, 261783 in 2018, 285926 in 2019).

Blood components were also collected by apheresis; in 2017-2019 a total of 103 RBC donations, 118125 plasma donations, 65224 PC donations, 260 GC donations and donations of two components simultaneously: $\mathrm{PC}$ and plasma - 64735 and $\mathrm{PC}$ and RBC - 160 .

A total number of components prepared for clinical use in 2017-2019 were as follows: 3615289 RBC units, 244219 therapeutic units of pooled PC, 155460 therapeutic units of apheresis PC, 4019081 units of fresh frozen plasma (FFP), 266 therapeutic units of GC and 114823 units of cryoprecipitate.

\section{National Blood Donor Register}

The European Union Directive 2002/98/EC imposed an obligation on the Member States to ensure the monitoring of the pathway from donor to recipient and vice versa (traceability) [2]. The Polish Blood Transfusion Act of $22^{\text {nd }}$ August 1997 requires the IHiT to run an electronic version of the National Blood Donors Register (Krajowy Rejestr Dawców Krwi, KRDK) [1]. The IT solution which ensured proper management of the KRDK was made possible as result of the implementation of the 2005-2008 project entitled "Establishment of the National Blood Donors Register" under the structural funds of the Sectoral Operational Program Improvement of the Competitiveness of Enterprises Measure 1.5: "Development of the system of entrepreneurs' access to information and public services on-line". The aim was to establish a digital platform for rapid information flow which would also guarantee security of the transmitted data. KRDK holds donor data received electronically and makes it available to CKiK. The KRDK resources serve to further strengthen the safety of blood by drawing upon the information on donor registration and eligibility for donation forwarded by other CKiKs [9].

Currently, the central database holds data on approximately 4 million donors and donor candidates. The IHiT verifies the data provided by CKiK on current basis, and the central database is maintained on the hardware infrastructure of the e-Health Center (CeZ). The significance of KRDK became a trigger for CeZ to start the e-blood project, the aim of which is to support the public BTS as well as to exercise supervision over optimal use of blood and blood components in therapy [10].

\section{Supervision over blood transfusion medicine}

Substantive supervision over blood transfusion medicine has been performed by the IHiT since 1951. IHiT is the entity responsible for supervision of all units of the public BTS dedicated to collection and issue of blood/blood components. As such, it is obliged to assemble information regarding the occurrence of adverse reactions related to the transfusion chain. The data is then subjected to analysis and any adverse event that might lead to such reactions is recorded (and analyzed). Among others, the tasks of IHiT include external inspections of $23 \mathrm{CKiK}$ (required for Minister of Health accreditation), consultations in transfusion medicine, development of training programs in transfusion medicine, provision of suggestions to the Minister of Health regarding donor qualification, and development of the good practices for implementation in CKiK, hospital blood banks and immunohematology laboratories [1].

Direct supervision over blood transfusion is also exercised by individual CKiK. Pursuant to applicable regulations, inspections are scheduled and performed every two years in CKiK, blood banks, immunohematology laboratories as well as in clinics and hospital wards where transfusion procedures are performed. Inspections in $23 \mathrm{CKiK}$ are the responsibility of $\mathrm{IHiT}$ and the CKiK perform inspections in the hospitals and laboratories of their region. Occasionally, IHiT becomes involved in hospital inspections. Each CKiK inspects the laboratories every two years and, 
if necessary, issues appropriate recommendations. Each CKiK is in turn inspected by IHiT every two years and recommendations are issued for correction of the detected non-compliances.

Inspections are performed in over 800 hospital based blood banks as well as in the hospitals which deal with blood transfusion. In addition, approximately in $600 \mathrm{im}$ munohematology laboratories are inspected.

\section{Quality Control of Testing Procedures}

In addition to inspections in CKiK and hospitals there is also the quality control of testing procedures used in transfusion medicine.

\section{Quality Assessment Programs in Polish Immunohematology Laboratories}

Participation in External Quality Assessment (EQA) programs is obligatory for all Polish immunohematology laboratories. The IHiT, which supervises the activities of CKiK in the field of transfusion immunology, participated at EQAs organized by ISBT Working Party on Immunohematology until the commercial EQA programs were launched and for many years participated in the red blood cell (RBC) immunology NEQAS (4 times/year). As the Reference Laboratory for Immunohematology in Poland, the IHiT has been organizing equivalent local EQAs for CKiK (23 participants every year). Immunohematology laboratories in hospitals are also mandated or obligated to participate in External Quality Assessment Program (EQAP). During the last 10 years almost 400 of these laboratories have participated in the National EQAP for Immunohematology Laboratories organized by IHiT (4 times/year) [11].

In the period 2004-2014 IHiT participated in all International Workshops on molecular blood group genotyping organized by ISBT [12]. Since $2015 \mathrm{IHiT}$ has participated in the commercial EQA for RBC genotyping and in the EQA program dedicated for RHD NIPT [13].

\section{Quality Control Programs for Platelet} and Leucocyte Immunohematology

Since $1990 \mathrm{IHiT}$ is an active participant of the European Symposium on Platelet and Granulocyte Immunobiology (ESPGI) operating under the auspices of International Society of Blood Transfusion (ISBT) [14, 15] that sets standards for serological and molecular diagnostics of antibody-mediated platelet or granulocyte disorders. IHiT as the Polish Reference Laboratory for immunohematology takes part in all EQAs organized by ESPGI. Since 2014 IHiT has organized own EQAs for CKiK performing serological and molecular studies in the field of platelet and leukocyte immunology [16]. Currently, there are three EQAs on platelet immunology: anti-human platelet antigen (HPA) detection (5 participants), HPA genotyping (2 participants), HPA-1a phenotyping (1 participant) and two for leukocyte immunology: anti-human leukocyte antigen (HLA) detection (10 participants) and anti-human neutrophil antigens (HNA) detection (1 participant).

\section{Quality control of screening tests for blood} transmitted pathogens in Polish blood donors The Quality Control of the screening methods of bloodborne infectious agents includes many activities ensuring reliability of procedures.

Prior to implementation of the screening method in CKiK both the tests and the equipment are carefully evaluated (for analytical and clinical sensitivity, specificity and correct identification of infected/contaminated donations). Before implementation into routine screening and after adaptation of procedure each CKiK performs validation of the test procedure using panels prepared by IHiT. Additionally, annual revalidation is performed for molecular tests. As required by the manufacturer, all CKiK apply an internal control added to each sample, positive and negative controls. In addition, all CKiK participate in periodic and daily EDCNet external quality control programs. Participation in the EDCNet program includes testing of positive control samples. Results are entered into the electronic system (EDCNet) on ongoing basis and are presented in the form of Levy-Jennings tables and charts. The obtained data are compared to previous CKiK results. The results are compared to those of other participants taking into consideration the same lot of controls, reagents, and testing strategies [17].

\section{Hemovigilance team}

Within the scope of hemovigilance over transfusion medicine the IHiT has established a special hemovigilance team (Team) which deals with analyses of adverse events and reactions. The main task of the Team is to evaluate the documentation on serious adverse events and reactions in hospitals and blood establishments forwarded to IHiT by CKiK with regard to compliance with the recommendations of the Polish Blood Transfusion Act of $22^{\text {nd }}$ August 1997 [1] for:

- completion and conformity with legal acts;

- substantial content, mainly assessment of hospital and/or CKiK procedures related to serious adverse events or reactions as well as compliance with applicable regulations including - among others - inspections, recommendations and control over their implementation.

The outcomes of these analyses are then used to prepare individual recommendations regarding the forwarded cases (in written form) and - if necessary - also general recommendations regarding transfusion safety.

The Team is also mandated to perform analyses of annual reports from CKiK which must include the reported adverse events and reactions. Following the conclusions of these analyses and taking into account the 
recommendations of European Commission experts (Common Approach for Definition of Reportable Serious Adverse Events and Reactions as Laid Down in the Blood Directive 2002/98/EC and Commission Directive 2005/61/EC), the Team prepares an annual report regarding serious adverse events and reactions to be approved by the Ministry of Health and then sent to the European Commission as SARE report $[2,18]$.

\section{Adverse events and reactions in Polish blood transfusion service}

The source of information on adverse events and reactions (AE/AR) (as defined by the Polish Blood Transfusion Act of $22^{\text {nd }}$ August 1997 and the Commission Directive 2005/61/EC of 30 September 2005 [1, 18]), with special emphasis on serious $A E / A R$, are the annual reports of CKIK as well as the documentation forwarded by CKiK to the Team.

Between 2015 and 2019 a total of 220 serious adverse reactions were reported in Polish recipients of blood and blood components which fulfilled the criteria of European Commission SARE report. There were two fatal adverse reactions. Most of the serious adverse reactions (135, $61.36 \%)$ were attributed to red blood cell transfusions. Serious adverse reactions were also reported among blood donors with 310 related to donation of blood/blood components.

There were also reports of 102 serious adverse events which occurred in CKiK and hospitals. Most of them (79, $77.45 \%)$ were attributed to human error.

\section{Implementation of novel methods of blood collection and preparation in Polish BTS}

Building up of safety and quality of blood components dedicated for clinical use requires implementation of advanced technologies for blood collection, preparation and testing. Due to rapid technological advancement automation in transfusion medicine has become more common [19]. Whole blood is separated into basic blood components: red blood cells (RBCs), platelet concentrates (PCs) and plasma. These components can then be subjected to additional preparation procedures to strengthen the safety of transfused blood components and meet the special needs of recipients. The same refers to blood components collected by apheresis [17].

In the 1980's, cell separators were initially used to collect plasma and subsequently for collection of PCs. Currently, about $40 \%$ of PCs issued for clinical purposes are obtained with cell separators as is approximately $12 \%$ of plasma units for clinical use. The use of apheresis technique is however limited with regard to red blood cell concentrates (RBCCs) due to high cost of the procedure and special donor requirements $[20,21]$.
The patients, who are alloimmunized for HLA and/or HPA antigens, require the use of PCs collected by apheresis. Transfusion of apheresis PCs also has increased the safety profile due to fewer donor exposures.

Despite this technological progress, WB collection remains the primary method of obtaining blood components for clinical use due to its logistical simplicity and convenience for the donors. The procedure of preparing blood components for clinical use requires specialized equipment both at WB collection and preparation. In Polish BTS many of the new methods are initially tested by IHiT prior to country-wide implementation.

\section{Leukoreduction}

Leukocytes which are present in blood components are implicated in causing post-transfusion adverse reactions such as: non-haemolytic febrile transfusion reactions (FNHTR), anti-HLA alloimmunization, resistance to platelet transfusions and transmission of intra-leukocyte infectious agents [22]. In the 1970's, a significant worldwide research effort was devoted to removal of leukocytes from blood dedicated for transfusion. In Poland, an infrequent use of leukocyte reduced (LR) blood components began at the end of the 1980ies. At first, partially LR components were obtained by centrifugation, which procedure was eventually replaced by more efficient leukocyte-removal filters. In the 1990ies, the obligatory depletion range was set at fewer than $5 \times 10^{6}$ leukocytes/therapeutic unit. This has been changed to $<1 \times 10^{6}$ which is now the standard across the $\operatorname{EU}[17,23]$. LR blood components are primarily reserved for patients who require multiple transfusions, for multiple recipients, recipients of PCs, stem cell and organ transplants candidates as well as for intrauterine and neonate transfusions. For prevention of cytomegalovirus (CMV) transmission, LR components are considered equivalent to the use of components from CMV-negative donors. Every year the number and proportion of transfused LR components are increasing. Starting on January $1^{\text {st }}, 2020$, all transfused PCs need to be leukoreduced, though the change is small considering that over $97 \%$ of PCs were already leukoreduced prior to that date. The situation is different for red blood cells, where the percentage of LR red blood cells, though increasing (2017 - 20.8\%, 2018 - 26.1\%, and 2019 $28.2 \%$ ), still remains below $30 \%$. A portion of LR red blood cells is also irradiated as patients' needs overlap between these two special blood components.

\section{Irradiation}

Since 1996, the Polish CKiK have been using gamma and later $\mathrm{X}$ irradiation for cellular blood components (RBCs, PCs and GCs). Irradiation inactivates immunocompetent lymphocytes T which - when transfused with cellular blood components - may induce Transfusion-Associated Graft versus Host Disease (TA-GvHD). Since there is no effective 
treatment for TA-GvHD, the only way to protect patients at risk of this serious adverse reaction is irradiation and some methods of pathogen inactivation (i.e. Intercept and Mirasol systems) [24, 25]. At present, we record sporadic use of only irradiation of RBCs and PCs. In 2019, only $0.06 \%$ of RBC was irradiated $(0.31 \%$ in $2018,0.12 \%$ in 2017). In 2019, the irradiated PCs also constituted only $0.04 \%$ of all obtained PCs $(1.37 \%$ in $2018,2.52 \%$ in 2017). In most cases, irradiated and leukoreduced RBC and PC are used. In 2019, 9.17\% of RBC were subjected to leukoreduction and irradiation (8.94\%, in 2018, 8.34\% in 2017). In the same year $54.63 \%$ of PCs were subjected to leukoreduction and irradiation $(58.07 \%$ in 2018 , $55.08 \%$ in 2017). In 2019 nationwide a total of $9.23 \%$ of RBCs $(9.25 \%$ in 2018, 8.46\% in 2017) - and $54.67 \%$ of PCs $(59.44 \%$ in $2018,57.60 \%$ in 2017$)$ - were subjected to irradiation. It should be emphasized that the majority of irradiated blood components are obtained in CKiK Iocated in the regions where there are clinics dedicated to treatment of patients at an increased risk of developing TA-GvHD.

\section{Pathogen inactivation}

Pathogen inactivation in plasma with the Theraflex MB system was implemented in Poland already in 2008. In 2009, the Mirasol PRT system for plasma and PC was installed in several CKiK. The aim was to obtain high-safety plasma as alternative to quarantine plasma [26]. Currently, in Poland, apart from the Mirasol system (26) and the Theraflex MB Plasma system (12) there is also the Intercept system in use ( 6 systems in 1 RCKiK) for pathogen inactivation in plasma and PCs. Since 2010 , countrywide $2.68 \%$ of plasma obtained at CKiK was subjected to inactivation $(2.75 \%$ in $2011,3.53$ in 2012). The recent years have not reported any significant increase in the percentage of inactivated plasma. In the period 2017-2019, countrywide $4-6 \%$ of plasma was subjected to inactivation. In 2019 however there was a slight increase in the percentage of inactivated plasma issued for clinical use. In 2019, 11.97\% of inactivated plasma was issued to hospitals as compared to $10.23 \%$ in 2018 and $8.0 \%$ in 2017. In the same years, the mean percentage of inactivated pooled PCs did not exceed $5 \%$; for apheresis PCs it was about 20\%. On the other hand, in the years 2017-2019 the percentage of inactivated PCs for clinical use did not exceed 12\% (11.87\% in 2019, $11.74 \%$ in $2018,11.41 \%$ in 2017). It can therefore be concluded that the pathogen inactivation systems installed in the Polish CKiK are underutilized. This may be explained by higher cost of inactivated blood components, lack of physicians' awareness of the advantage of using higher safety components as well as no yet available method for pathogen inactivation of red blood cells which are the most frequently transfused blood component.

\section{Freezing and cryopreservation}

Freezing of plasma dedicated for clinical use is the only way to secure the needs of patients for this blood component. At present, approximately $20-25 \%$ of the plasma obtained at CKiK is dedicated for clinical use as fresh frozen plasma (FFP). The remaining amount is intended for fractionation into blood derived biological products such as albumin, immunoglobulins and clotting factor concentrates. The only equipment required for freezing of plasma are special freezers that ensure component temperature of $-30^{\circ} \mathrm{C}$ within 60 minutes.

Cryopreservation of cellular blood components requires, appropriate cryoprotective techniques and agents on top of high-tech freezing equipment. At the turn of the 1940's and 50's techniques for freezing living cells were applied using at first glycerol as cryoprotective agent and then DMSO. In Poland, the first studies related to cell freezing were performed in the 1960's [27-29]. It should be recognized that frozen blood components are indicated under limited and defined circumstances which also include military purposes. Frozen blood components should be primarily treated as a security reserve of RBCs for rare blood groups in the red cell antigen system and specific HLA and/or HPA antigens. RBCs freezing is currently rather sporadic; only 4 CKiK have this procedure in use, mainly WCKiK. In the consecutive years the following amounts of RBCs were frozen; 34 units in 2017, 28 in 2018 and 36 units in 2019.

The countrywide percentage of frozen PCs amounted to approx. 3\% in 2019 but in some RCKiK it was significantly higher - even up to approximately 35\% [21]. However, a downward trend is observed every year; $4.64 \%$, in 2017 and $3.7 \%$ in 2018.

\section{Automation of preparation processes}

The safety and quality of blood components dedicated for clinical use must be secured to the highest possible degree. Automation of procedures is one of the factors that contributes to improvement of blood component parameters. Automation applies both to collection and testing, but also to preparation. In Poland, the first step to implementation of automated methods was made in the 1990's with the introduction of automatic presses for separation of blood into components which are nowadays used by all CKiK. Along with technological advancement a growing number of IT-controlled equipment is implemented to markedly eliminate the operator's interference into the process and to ensure its stability. Special plasma freezing devices guarantee high quality parameters, in particular, high content of factor VIII. In 2005, the first automated devices for obtaining pooled PCs appeared in Poland [30] and they were used to obtain $40.5 \%$ of pooled PCs in 2017 followed by $36.3 \%$ in 2018 and then $30.6 \%$ in 2019 . The decreasing percentage is primarily due to the high cost of specialized disposable 
kits. It should be remembered however, that automation allows to reduce the number of qualified personnel involved in the process of blood component preparation.

\section{Tests for transfusion medicine}

Preparing blood for transfusion requires immunohematology tests as well as testing for infectious markers. Routine immunohematology tests are performed in hospital immunohematology laboratories (HIL) and indeterminate results are consulted in CKiK laboratories or - in more complicated cases - with IHiT which acts as the reference laboratory. Donor testing for infectious disease markers is a prerequisite to obtaining safe blood components. This is the responsibility of CKiK and the IHiT becomes involved when the results are complex and require verification and confirmation of initial test results.

\section{Obligatory screening of Polish blood donors} for pathogens transmitted by blood/blood components - range and methodology Panel of molecular (HCV RNA since 2002, HIV RNA and HBV DNA since 2005) and serological (HBsAg, anti-HCV, anti-HIV and antibodies to Treponema Pallidum) markers of blood-borne infectious agents are tested in all blood donors. Screening for antigens: HIV p24 and core HCV Ag are recommended, but not obligatory [17, 31].

At the beginning of 2021, 23 CKiK performed serological tests and 18 of them also used molecular biology methods. The entire process of testing for screening markers is fully automated. All methods are CE-marked and meet requirements of Directive 2002/98 EU and recommendations of the Council of Europe [2, 32]. Screening with molecular techniques is carried out using real-time polymerase chain reaction (RT-PCR) on the Cobas 6800 (Roche) in plasma minipools from 6 donations (MP6) in $10 \mathrm{CKiKs}$, and transcription mediated assay (TMA) on the Panther (Grifols) in individual donations in 4 CKiKs and in MP4 in 4 CKiKs. The sensitivity of nucleic acid detection depends on assay sensitivity and the number of donations in MP: for HCV RNA it is estimated at $3-42 \mathrm{IU} / \mathrm{mL}$, HIV RNA at $18-154.2 \mathrm{IU} / \mathrm{mL}$ and HBV DNA at $4.5-17.2 \mathrm{IU} / \mathrm{mL}$. Clinical sensitivity and specificity of serological tests is $>99.1 \%$ and $>99.6 \%$ respectively and it is based on chemiluminescence (Abbott: Alinity $\mathrm{i}-3$ CKiKs, Alinity s -1 CKiK, Architect -5 CKiKs), electrochemiluminescence (Roche, Cobas e602-9 CKiKs) and ELISA (BioRad, Evolis - 5 CKiKs) [33-35].

Blood borne infectious agents not obligatory for all Polish donors; epidemiology

Parvovirus B19 (B19V) DNA and hepatitis A virus (HAV) RNA screening is performed in plasma for fractionation according to fractionators requirements [17]. For B19V it is also based on European Pharmacopeia which recommends the deferral of only high viral load donations that may contaminate the production pool $>10^{4} \mathrm{IU} / \mathrm{mL}$. Until 2020, tests for B19V DNA and HAV RNA were performed in CKiK laboratories, recently however testing was moved to fractionation facilities.

High viral load B19V infected donors are deferred for a minimum of 12 months and for HAV initial deferral is 4 months.

The incidence of high viral load B19V depends on the year and is generally higher in epidemic years; the range is from 23 to 47 per 100000 donors. HAV infections were not detected until outbreak. In the period 2017-18, 17 infected donors [frequency: $2.6 / 100000$ donors, $95 \%$ confidence interval (Cl): 1.4-3.7/100 000] and two likely transfusion related transmissions were identified [36].

In Poland there is no recommendation to screen HEV RNA like in other European countries. Based on a 2015 study, the frequency of HEV RNA was 47.4 (95\% Cl: $21.7-$ -103.3)/100 000 first-time donors, and anti-HEV IgG antibodies were found in $43.5 \%$ (95\% Cl: 41.8-45.3\%) donors [37].

\section{Epidemiology of HBV, HCV}

\section{and HIV infections; 2005-2018}

The frequency $(95 \% \mathrm{Cl})$ of anti-HCV antibodies decreased significantly from 368 (95\% Cl: 342-394) in 2010 to 105 (95\% Cl: 89-121) in 2018 per 100000 first-time donors (FTD) and from 12.9 (95\% Cl: 8.7-17.1) in 2006 to 5.2 (95\% Cl: 3.1-7.3) in 2018 per 100000 repeat donors (RD). In FTD a significant decrease was noted in the $>50$ age groups [38].

The decreased frequency for HBsAg positive infections was found among both FTD: from 601 (95\% Cl: 567-635) to 126 (95\% Cl: 109-145) per 100000 and RD: from 7.6 (95\% Cl: $4.9-11.7)$ to 0.2 (95\% Cl: 0-1.2) per 100000 between 2005 and 2018. The most significant decrease of HBsAg detection among FTD was recorded in the age group $\leq 20$, significant changes were not observed in donors $>50$ years of age [38].

$75 \mathrm{HCV}$ window period cases (WP) (9.3, 95\% Cl: 7.4-11.6/ /100 000 donors) were identified during 14 years, the majority of seronegative infections were detected for HBV: 184 occult infections $(\mathrm{OBI})$, [frequency/1 million donors -22.7 (95\% Cl: 19.7-26.3)] and 47 in serological WP (5.8, 95\% Cl: 4.4-7.7/1 million donors) [38].

In the 2005-2018 period, 542 HIV infected donors were identified, 519 of whom were found seropositive 6.26 (95\% Cl: $5.77-6.85) / 1$ million donors and 23 seronegative -0.28 (95\% Cl: $0.19-0.42) / 1$ million donors. Higher HIV detection rate was observed in FTD than RD as well as among men than women. In 2018 the first Western blot positive and HIV-RNA nonreactive donor was identified. During the study period a slight increase trend in HIV infection rate was observed ranging from 4.9 (95\% Cl: 
2.90-6.91) in 2005 to 9.16 (95\% Cl: 6.72-11.61)/1 million donors in 2009 [39]. This may be explained by epidemiological changes in the general population as well as growing number of test seekers anxious for information on their serological status but also on the viral RNA in their blood.

\section{Red blood cell immunohematology tests: organization and scope}

Immunological tests performed in blood donors including all $\mathrm{ABO}$ and $\mathrm{RhD}$ blood group tests as well as detection of irregular antibodies are performed in the headquarters of the CKiK and indeterminate cases are referred to IHiT.

It is recommended to determine $\mathrm{K}$ antigen in all donors and $\mathrm{Rh}$ phenotype in all regular donors. If possible, $\mathrm{k}$ antigen should be determined in $\mathrm{K}$ antigen positive donors and the clinically significant antigens of other group systems (Duffy, Kidd, MNS) should be determined in regular donors especially group 0 . For rare blood types it is recommended to use molecular biology methods to identify donors without high prevalence antigens [40-43]. In identified donors, the results should be confirmed by serological methods. The tests are also performed at IHiT as consultations.

Hospital immunohematology laboratories (HIL) perform $\mathrm{ABO}$ and RhD typing, screening for red blood cell alloantibodies, compatibility testing and qualification tests for Ig anti-D immunoglobulin administration during pregnancy and following delivery in RhD negative women. The scope of pre-transfusion tests, requirements for personnel qualifications and quality control criteria for HIL must follow the legal acts [44, 45]. According to 2018 survey there were $583 \mathrm{HIL}$ and the number decreased by 17 (30\% managed by external companies) as compared to the 2015 survey $[46,47]$. The total number of tests performed in Poland was $396216 /$ month. Approximately 4000 people are employed in HILs; 59\% are higher education staff; $67 \%$ of laboratories were headed by laboratory diagnostician or medical doctor (MD) specialized in transfusion medicine. In $42 \%$ of laboratories blood group and compatibility testing is performed with automated or semi-automated techniques. Test results are approved by diagnosticians or MD in $89 \%$ of laboratories. All but one HIL participated in external quality assessment (EQA) programs.

\section{Immunohematological testing in patients with auto- and allo antibodies against red blood cell antigens}

Immunohematological testing in patients with auto- and allo-antibodies is performed in the reference laboratories at CKiK and IHiT. They include alloantibody identification, determination of phenotypes, diagnostics of autoimmune hemolytic anemia (AlHA) and hemolytic disease of the newborn (HDFN), immunohematological tests before and after stem cells transplantation and pre-transfusion testing in daratumumab (DARA) treated patients. The suitable procedures for DARA patients were introduced as soon as this treatment became available in Poland [48]. Highly specialized tests with the use of rare RBC and rare sera (from the international exchange) and molecular techniques are performed in IHiT for patients with antibodies against high or low frequency antigens [49]. Between the years 2000-2017, alloantibodies against 24 different high frequency antigens (HFA) were detected in 316 patients. 11\% of these 24 alloantibodies were of clinically significant, $50 \%$ sometimes destroyed incompatible RBCs and 39\% were insignificant [50]. The modern methods of serological and molecular testing are introduced in consultation testing in line with the progress of knowledge and availability of tests [e.g. tests with recombinant blood group antigens ( $\mathrm{rBGA})$ ].

\section{Medical care for pregnant women with red blood cell alloimmunization during pregnancy}

Red blood cell (RBC) alloantibodies detected in $~ 1 / 300$ -600 pregnancies, in $\sim 50 \%$ of such cases may lead to hemolytic disease of fetus and newborns (HDFN). The presence of RBC antibodies also increases transfusion risks in both mother and fetus/newborn. To identify this risk blood typing ( $\mathrm{ABO}$ and $\mathrm{D})$ and screening for red cell antibodies in pregnant women are necessary; paternal phenotyping/ /genotyping, fetal genotyping (non-invasive prenatal testing i.e. NIPT or amniocentesis) may be recommended. The mother with alloantibodies should undergo extended phenotyping of the Rh (including $\mathrm{C}^{\mathrm{w}}$ antigen), Duffy, Kidd and MNS systems. The third trimester screening may detect RBC antibodies not present or undetected in the first trimester screening and cause HDFN. Anti-D Ig prophylaxis has been remarkably successful in reducing the number of sensitizations to $D$ antigen (from $7-13 \%$ to $0,5 \%$ after post-delivery and to $0.1-0.3 \%$ after antenatal immunoprophylaxis); special attention should be paid to immunization against non-D antigens including Rhc, RhE, $\mathrm{K}$ (non-D antibodies in $0.37 \%$ of RhD positive pregnant women) [51, 52]. Any suspected cases with antibodies against common (HFA), rare (LFA) or multispecific antigens are consulted at the IHiT. The number of such cases remains unchanged at $\sim 40 /$ year. All the tests, especially genetic typing (confirmation of maternal D status, NIPT for D, C, E, K antigens) are performed in the IHiT [52].

\section{Diagnostics of fetal/neonatal alloimmune thrombocytopenia (FNAIT) in Poland}

Fetal/neonatal alloimmune thrombocytopenia (FNAIT) is a rare disease $(\sim 1 / 1,000)$ [53], which occurs when maternal antibodies destroy fetal/neonatal platelets presenting incompatible HPA. Since 1980s IHiT has been conducting FNAIT diagnostics, initially using platelet immunofluorescence assay and then monoclonal antibody immobilization of platelet antigens (MAIPA) test and HPA 
genotyping [53]. Until 2000 the number of diagnosed FNAIT cases was $\sim 20 /$ year ( 8/year were confirmed as FNAIT). In the PREVFNAIT program performed in the 2013-2017 period HPA-1a was tested in 24236 pregnant women and $2.4 \%$ HPA-1a negative women were identified. In $9.1 \%$ of them anti-HPA-1a were detected and FNAIT was observed in $40.6 \%$ of immunized women $[54,55]$. PREVFNAIT experience improved diagnostic algorithm for FNAIT caused by anti-HPA-1a which includes identification of HPA-1a phenotype/genotype in mother and father and monitoring of HPA-1a antibodies by PAKLX test and quantitative MAIPA during pregnancy. HLA $D R B 3{ }^{*} 01: 01$ genotyping of HPA-1a negative pregnant women is performed to determine the risk of alloimmunization. Non-invasive diagnostics of HPA-1a genotype in the fetus (NIPT) from plasma of immunized women to confirm/exclude the risk of fetal disease in mothers with anti-HPA-1a is also available $[55,56]$. During the time the routine number of cases diagnosed toward FNAIT increased to $\sim 60 /$ year ( $25 /$ year ultimately confirmed as FNAIT).

\section{Selection of platelet donors}

\section{for platelet refractory patients}

Platelet transfusions became available in Poland in the late 1970's and since then immunological background of platelet refractoriness was studied using lymphocytoxicity test (LCT) at IHiT and several CKiK. The LCT cross-match for choosing the donors to achieve adequate post-transfusion platelet count increments was introduced and it is used until now [57]. In the early 1980's the registry of donors tested for HLA class I antigens was organized at the IHiT. In the early 1990's the donors were also typed for HPA to provide the HPA compatible PC for patients with anti-HPA-1a antibodies - mainly for newborns with alloimmune thrombocytopenia [58]. According to the survey performed between January 2015-July 2016, the demand for compatible PCs was as follows: 1788 PCs for patients with anti-HLA, 63 with anti-HPA and 58 with anti-HLA/anti-HPA antibodies. FNAIT neonates were transfused with 35 PCs from HPA compatible donors and with 176 PCs from random donors. Currently 13/21 CKiK are involved in such activity and perform HLA and HPA typing to expand the donor pool which size and diversity is still smaller than in other countries. Until December 2018 the CKiK registers reported 12885 donors typed for HLA class I antigens including 417 donors typed for HPA and 5872 donors tested minimum for HPA-1a phenotype/genotype including 133 HPA-1a negative donors [59]. Several modern methods for anti-HLA antibody detection have been implemented in Polish laboratories (Lambda Antigen Tray - Mixed Class I \& II - ELISA, MAIPA-HLA, Luminex assays e.g. LABScreen Mixed Class I \&ll, LABScreen Single Antigen HLA Class I or II for determination of specificity.

\section{Transfusion-related acute lung injury} diagnostics

Transfusion-related acute lung injury (TRALI) is recognized as one of the most severe adverse post-transfusion reactions, with acute respiratory failure within 6 hours after transfusion in the absence of circulatory overload. The incidence of TRALI is estimated at $\sim 0.02 \% /$ blood unit. Serological and genetic diagnosis of TRALI has been performed at IHiT since the 1990's [60] and includes anti-HNA and anti-HLA tests as well as HNA and HLA genotyping in both blood donors and recipients [61]. Between 2006 and 2012, 271 cases of post transfusion reactions (PTR) with dyspnoea were analyzed in the IHiT; 464 blood components were transfused; among them there were 33 diagnosed TRALI. Anti-leukocyte antibodies were detected in $18.2 \%$ of blood components (3 RBCCs, 3 FFP) [62]. Recently, Luminex anti-HNA and anti-HLA antibody tests have been implemented to complement the MAIGA, GAT and GIFT tests. In 2014-2019, 113 patients with PTR and 115 blood components were analyzed in IHiT: 36 cases of TRALI induced by anti-leukocyte antibodies were diagnosed. Anti-leukocyte antibodies were detected in $17 \%$ of blood components (13 FFP, 1-LR PCs, 1-LR PCs pooled, 4 RBCCs [63]. IHiT follows the international guidelines for the diagnosis of TRALI and recommends the successive implementation of TRALI preventive measures in Poland; plasma from donors with a history of transfusion and screening for the presence of antibodies in blood donors implicated in TRALI are not issued for clinical use [17].

\section{Molecular diagnostics of red blood cell, platelet and granulocyte antigens}

Molecular diagnostics of blood cell antigens began at IHiT in the 1990's with human platelet (HPA) and granulocyte (HNA) antigen genotyping for diagnostics of fetal/neonatal alloimmune thrombocytopenia (FNAIT) and granulocytopenia (NAIG) $[64,65]$ as well as for development of HPA-determined panels for diagnostics of anti-HPA specificity and also for providing HPA compatible donors for FNAIT and platelet refractory patients. In the 2000's red blood cell antigen genotyping started from non-invasive prenatal testing of fetal $\mathrm{RhD}$ and other antigens for immunized pregnant women. Then research was focused on $R H D$ alleles. D variants were detected in $0.2 \%$ RhD-negative blood donors: $60 \%$ of alleles encoded potentially immunogenic $\mathrm{RhD}$ [66]. In blood donors/recipients with discrepant results of $\mathrm{RhD}$ in $79 \%$ of cases $R H D * 01 W .1,{ }^{*} 01 W .2$ and ${ }^{*} 01 W .3$ were identified as not leading to alloimmunization [67]. Genotyping of RBC antigens has also been used in the diagnostics of antibodies in recently transfused or AlHA patients, alloimmunized patients with antibodies against HFA and in screening compatible donors for such blood recipients [41-43]. Currently, a large spectrum of methods [i.e. digital PCR, Sanger and next generation sequencing (NGS)] is used at 
the IHiT to resolve discrepant results of serological cases from all over Poland which leads to determination of new alleles encoding blood group antigens [66, 68-70].

\section{Non-invasive prenatal testing of fetal blood group and platelet antigen genotypes}

In 2000 non-invasive prenatal testing (NIPT) based on cellfree fetal DNA circulating in plasma of pregnant women was introduced for diagnostics of feto-maternal incompatibilities at the IHiT. For 18 years NIPT based on real-time PCR technique has been implemented at first for prediction of fetal $\mathrm{D}$ antigen in RhD-negative pregnant women with anti-D and then in 2008, for pregnant women with anti-c, anti-E, anti-K and recently with anti-HPA-1a antibodies, detecting fetal compatible genotype in $24-51 \%$ of cases [71]. Since 2015 NIPT has been used for fetal RHD screening in non-immunized RhD-negative pregnant women for targeted antenatal anti-D immunoprophylaxis predicting fetal RhD-negative status in 34\% of tested pregnancies [72]. Modern technologies (NGS and digital PCR) are currently analyzed for NIPT at the IHIT [73].

\section{New methods of studying the mechanisms of red blood cells (RBCs) destruction}

In addition to research activities which are fundamental for the current needs of transfusion medicine, other studies are also ongoing such as investigation of mechanisms of red cell destruction.

Antibody-coated RBCs are destroyed by macrophages. Assessment of phagocytosis by monocytes (precursors of macrophages) can be used in predicting the clinical significance of antibodies in vivo. So far, this process was evaluated by microscopic monocyte monolayer assay. Application of flow cytometry (FC) with antibodies specific to RBCs (anti-CD235a) and monocytes (anti-CD14) enabled their clear separation from monocytes with engulfed erythrocytes. The quantitative evaluation was supplemented with microscopic sequential erythrophagocytosis registration and confocal microscopy studies that allowed the construction of a spatial model of erythrophagocytosis.

Senescence of RBCs under routine storage conditions was also considered among mechanisms of RBCs destruction. This is called erythrocyte storage lesion which may induce adverse clinical outcomes. FC was useful for measurement of expression level of surface CD molecules: CD44, CD47, CD55, CD59, CD235a, which are important for physiological function as well as removal of erythrocytes. These markers were compared between fresh and stored RBCs. In addition, phagocytosis was also evaluated.

During RBCs senescence and storage microvesicles are released. Their accumulation in the stored RBCs units may be responsible for inflammation and/or thrombotic events in transfusion recipients. Qualitative and quantitative analysis of the microvesicles, their release and phagocytosis were assessed using FC evaluation and confocal microscopy [74-76].

\section{Other activities of blood establishments}

CKiK activities are related not solely to the collection, testing, preparation and issue of blood/blood components for clinical use but also to other important task such as consultations for transfusion medicine and special consultation tests for donors (CKiK and IHiT). This activity also relates to other branches of medicine such as transplantology. There are 2 tissue banks (in Katowice and Kielce) and 4 hematopoietic cell banks (in Bydgoszcz, Kielce, Poznań, IHiT). Six bone marrow donor centers were organized (in Białystok, Katowice, Kielce, Lublin, Poznań, IHiT) and the CKiK in Bydgoszcz and IHiT are also centers where hematopoietic cells are collected. Other medical procedures are also performed at IHiT and CKiK.

For many years now, the IHiT has also been involved in the preparation of components intended for patients needing highly sophisticated treatment options such as: platelet gel and platelet glue, fibrin glue and artificial tears $[77,78]$. The procedures developed at the IHiT have been made accessible to CKiKs to ensure easier availability for patients in their region.

Moreover, the Polish blood transfusion service is involved in activities related to the manufacturing of medical products.

\section{Therapeutic apheresis}

Typically the aim of therapeutic apheresis (TA) is to remove or reduce the concentration of pathological agents present in the patient's blood (blood cells, plasma components); in some cases the goal is supplementation of blood components or extracorporeal modification.

In the $20^{\text {th }}$ century IHiT was one of the first Polish medical facilities to use TA and in the $21^{\text {st }}$ century, the procedure has already become routine. Between 2000-2020, a total of 4,166 TA procedures were performed at the IHiT (3,012 plasma exchanges, 789 leukocytapheresis, 276 photopheresis and 89 thrombocytapheresis). Currently, these procedures are also performed in some other hospitals and CKiK [79]. As example RCKiK in Bialystok performed over 3,800 TA in the last 20 years ( mainly plasmapheresis $(2,611)$, erythrapheresis $(1,071)$, leukapheresis (149).

At the IHiT, the TA procedures were mainly used in haemoproliferative disorders. Most plasma exchange procedures were performed to eliminate excessive pathogenic proteins in multiple myeloma patients. Since 2007 however the number of procedures for such causes has gradually decreased as new treatment options were implemented. The second most frequent indication for plasma exchange was 
thrombotic thrombocytopenic purpura (TTP). Other medical entities/hospitals performed TA procedures mainly for neurological indications, including Guillain-Barré syndrome. In most cases TA procedures were performed following recommendations of the American Society for Apheresis (ASFA), although not always for category I indications [80].

In general, the procedures were well tolerated; vasovagal reactions, mild symptoms of hypocalcaemia and problems with venous access were sporadically observed. TA was primarily used as a supportive and palliative procedure for the rapid elimination of pathogens from circulation.

\section{Donor recruitment and donor-recipient matching in Polish Blood Transfusion Service}

Until 1997 only autotransplantations and hematopoietic cell transplantations from a matched sibling donor (MSD) were performed in Poland [81]. At the beginning of the $21^{\text {st }}$ century first registries of unrelated bone marrow donors were established in Poland and from the very beginning blood transfusion service was involved in donor recruitment. The number of unrelated bone marrow donors recruited by the CKiK and the IHiT increased from 4160 in 2002 to 171513 in 2019 [82, 83]. The recruited bone marrow donors are a significant contribution to the overall pool of Polish unrelated bone marrow donors (2019 1774 285). From the point of view of immunogenetics, ethnicity and logistics Polish donors are best suited for treatment of patients in national bone marrow transplant centers. Altruism of potential donors and efforts of the staff in centers for recruitment, matching and transplantation have raised the number of unrelated HSC transplants in Poland from 64 in 2001 to 423 in 2019, including 265 (63\%) from Polish donors. Currently $93 \%$ of matching procedures end with the selection of an acceptable bone marrow donor, as compared with 51\% in 2006. The quality and safety of transplant procedures was improved by increasing the percentage of transplants from fully HLA-matched unrelated donor; 54\% in 2007 to $84 \%$ in 2019. When no fully compatible donor of hematopoietic cells is available measures have been implemented to reduce the incidence of severe and chronic graft-versus-host disease and to improve recipient survival through population-based methods of precise selection of extended HLA haplotypes in donors [84]. The selection of beneficial donor in terms of the number of HLA-KIR cognate pairs has contributed to significant reduction of relapse rate for leukemias and other cancers $[85,86]$. For the last 20 years, a shift was made from the unreliable serological method of tissue typing of donors and recipients to molecular methods based on SSP and SSOP techniques. More and more centers use modern methods of direct gene sequencing (Sanger, NGS) for tissue typing, which only improves the safety of patients undergoing hematopoietic cell transplantation.
Immunoglobulin anti-D and anti-HBs

In the early 1980's, the IHiT together with "Biomed" Serum and Vaccine Production Plant (PLC in Lublin) developed the technology for production of anti-D and anti-HBs immunoglobulins (based on the Cohn fractionation method) which was finalized by registration of these medical blood products and implementation for routine use of Gamma anti-D 150 since 1986 (Gamma anti-D 50 since 1989) and Gamma anti HBs (200 and 1000) since 1990 [87-89].

Gamma anti-D prevents alloimmunization in RhD-negative women. It is administered after childbirth, during pregnancy, following miscarriage and after diagnostic amniocentesis beyond $12^{\text {th }}$ week of pregnancy. Plasma for Gamma anti-D production is collected in CKiK from RhD-negative donors previously immunized to produce antibodies. Currently, the main source are donors who were immunized many years ago. Some CKiK however plan to return to immunization procedures.

Gamma anti-HBs is used in immunoprophylaxis of hepatitis $B$, in newborns of hepatitis $B$ mothers, in children with body weight $<50 \mathrm{~kg}$ at particular risk of hospital HBV infection.

According to national guidelines Gamma anti-D and Gamma anti-HBs are produced from plasma collected in CKiK from donors with high titer antibodies. The risk of transmission of infectious agents is reduced by screening plasma pools for infectious markers (HCV, HBV, HIV, HAV, B19V) and by pathogen inactivation during the production process. In the years 2018-2020, the "Biomed" produced 33368 vials of Gamma anti-HBs 50, 73563 vials of Gamma anti D 150 (not sufficient to meet $100 \%$ of the demand) as well as 9736 vials of Gamma anti-HBs 200. Medical product batch release for Gamma anti-D is performed at the IHiT and for Gamma anti-HBs - at the National Institute of Public Health - National Institute of Hygiene (PZH).

As mentioned earlier, the implementation of non-invasive prenatal testing (NIPT) with respect to all RhD-negative women during pregnancy would limit the need for anti-D immunoglobulin administration.

\section{Convalescent plasma, anti-SARS-Co2-V immunoglobulin}

Polish BTS has been collecting COVID-19 convalescent plasma (CCP) since April 2020. Donors qualified for CCP donation must provide proof of being infected with SARS-CoV-2 and fulfil the eligibility criteria for regular blood donors. Only about a third of convalescent donors have high titer antibodies. More than a half of CCP donors have low titer antibodies or no antibodies at all which renders their plasma unacceptable for treatment of COVID-19 patients. Until April 2021, 49715 CCP donations were collected (mainly by apheresis) and 66334 units were transfused to infected patients. All transfused CCP units were pathogen inactivated. 
At the same time, the IHiT in cooperation with the Department and Clinic of Infectious Diseases of the Medical University of Lublin and the "Biomed" participates in the project of the Medical Research Agency entitled "Studies on the production of specific human immunoglobulin from plasma of donors with history of SARS-CoV-2 and its use for treatment of COVID-19 patients". The project involves research on the process of producing anti-SARS-CoV-2 immunoglobulin and conducting clinical trials on the use of the product in COVID-19 patients. Laboratory testing of plasma, the intermediates and the anti-SARS-CoV- 2 immunoglobulin-final product were performed. The tests concerned qualitative methods of determining IgG antibody level and anti-SARS-CoV-2 neutralizing antibody titer. The stability of anti-SARS-CoV-2 immunoglobulin was confirmed and clinical trials are underway. Anti-SARS-CoV-2 immunoglobulin is administered to hospitalized patients with RT-PCR confirmed SARS-CoV-2 infection to ensure the safety and efficacy of this medical product. The endpoint of the project is to evaluate the impact of the therapy on disease progression, survival as well as on the demand for mechanical ventilation and hospitalization.

\section{Summary}

For many years now the BTS in our country has played a significant role in the management and health care of Polish patients. The implementation of novel methods and ongoing research positions our BTS among those of highly developed countries. Nevertheless in some hospitals the awareness of the importance of proper management of blood therapy is still insufficient [90].

It should also be emphasized that the Polish BTS is engaged in activities related to other fields of medicine and largely contributes to creating additional treatment options.

\section{Authors' contributions}

JAP, EB, EL, MŁ, PG - design of study. All authors collection of data and manuscript writing, revision and approval.

\section{Conflict of interest \\ None.}

\section{Financial support \\ None.}

\section{Ethics}

The work described in this article has been carried out in accordance with the Code of Ethics of the World Medical Association (Declaration of Helsinki) for experiments involving humans; EU Directive 2010/63/EU for animal experiments; Uniform Requirements for Manuscripts submitted to Biomedical Journals.

\section{References}

1. Ustawa o publicznej służbie krwi. https://lexlege.pl/ustawa-o-publicznej-sluzbie-krwi/ (April 9, 2021).

2. Directive $2002 / 98 / E C$ of the European Parliament and of the Council of 27 January 2003 setting standards of quality and safety for the collection, testing, processing, storage and distribution of human blood and blood components and amending Directive 2001/83/EC. OJ L 33, 8.2.2003, p. 30-40.

3. Żak A, Lachert E, Antoniewicz-Papis J, et al. Ocena jakości ubogoleukocytarnych koncentratów krwinek czerwonych zamrażanych i rozmrażanych w systemie ACP 215. J Transf Med. 2011; 1: 32-43.

4. Olszewski A, Korzeniewski K, Lass A. Selected epidemiological aspects of fresh whole blood application in the Polish Field Hospital in Afghanistan. Int Marit Health. 2014; 65(1): 23-27, doi: 10.5603/ /MH.2014.0006, indexed in Pubmed: 24677124.

5. Olszewski A, Machała W. Chodzący bank krwi w wojskowym szpitalu polowym w Afganistanie. Lek Wojsk. 2014; 92(1): 65-71.

6. Ustawa z dnia 6 listopada 2008 r. o konsultantach w ochronie zdrowia (Dz.U. 2009 nr 52 poz. 419). https://isap.sejm.gov.pl/isap.nsf/DocDetails.xsp?id=WDU20090520419 (April 9, 2021).

7. Heier HE, Badloe J, Bohonek M, et al. Use of tranexamic acid in bleeding combat casualties. Mil Med. 2015; 180(8): 844-846, doi: 10.7205/MILMED-D-14-00592, indexed in Pubmed: 26226523.

8. NATO Medical Blood Advisory Team (MBAT). Position statement. The use of tranexamic (TXA) in bleeding combat. Draft 3 (Nov 29, 2011).

9. Antoniewicz-Papis J. Informatyzacja publicznej służby krwi jako element zarządzania ryzykiem w krwiodawstwie i krwiolecznictwie. Instytut Hematologii i Transfuzjologii, Warszawa 2016.

10. Projekt e-Krew. https://cez.gov.pl/projekty/realizowane/projekt-e-krew (April 9, 2021).

11. Pelc-Kłopotowska M, Michalik M, Łopieńska H, et al. Polish External Quality Assessment Scheme for Blood Transfusion Laboratories: 5-year experience in conducting the program. Vox Sang. 2015; 109(Suppl 1): 266.

12. Daniels G, van der Schoot CE, Olsson ML. Report of the fourth International Workshop on molecular blood group genotyping. Vox Sang. 2011; 101(4): 327-332, doi: 10.1111/j.1423-0410.2011.01540.x, indexed in Pubmed: 21895679.

13. Clausen FB, Barrett AN. Noninvasive Fetal RHD Genotyping EQA2017 Working Group. Noninvasive fetal RHD genotyping to guide targeted anti-D prophylaxis-an external quality assessment workshop. Vox Sang. 2019; 114: 386-393.

14. Lucas GF, Carrington PA. Results of the First International Granulocyte Serology Workshop. Vox Sang. 1990; 59(4): 251-256, doi: 10.1111/ /j.1423-0410.1990.tb00249.x.

15. Metcalfe P, Waters AH. Report on the fourth ISBT/ICSH platelet serology workshop (London 1988). Vox Sang. 1990; 58(2): 170-175, doi: 10.1111/j.1423-0410.1990.tb02084.x, indexed in Pubmed: 2339523.

16. Guz K, Łopacz P, Gierszon A, et al. Ocena dostępności dawców koncentratów krwinek płytkowych o oznaczonych antygenach leukocytarnych i płytkowych dla pacjentów z przeciwciałami anty-HLA i/lub anty-HPA. J Transfus Med. 2019; 12(1): 1-12, doi: 10.5603/jtm.2019.0012.

17. Obwieszczenie Ministra Zdrowia z dnia 30 marca 2021 r. w sprawie wymagań dobrej praktyki pobierania krwi i jej składników, badania, preparatyki, przechowywania, wydawania i transportu dla jednostek organizacyjnych publicznej służby krwi (Dz. U. MZ, poz. 28, 2021). http://www.dziennikmz.mz.gov.pl/DUM_MZ/2021/28/oryginal/akt. pdf (April 9, 2021). 
18. Commission Directive 2005/61/EC of 30 September 2005 implementing Directive 2002/98/EC of the European Parliament and of the Council as regards traceability requirements and notification of serious adverse reactions and events. OJ L 256, 1.10.2005, p. 32-40.

19. Antoniewicz-Papis J. Nowoczesne metody pobierania i preparatyki krwi i jej składników. Laboratorium. 2006; 5: 48-51.

20. Rosiek A, Tomaszewska A, Lachert E, et al. Działalność jednostek organizacyjnych służby krwi w Polsce w 2018 roku. J Transf Med. 2019; 12: 127-143.

21. Rosiek A, Tomaszewska A, Lachert E, et al. Blood transfusion service in Poland in 2018. J Transf Med. 2019; 12(4): 144-159, doi: 10.5603/jtm.2019.0008.

22. Antoniewicz-Papis J. Ubogoleukocytarne składniki krwi - otrzymywanie i zastosowanie. Laboratorium. 2007; 11: 24-27.

23. Krwiodawstwo zbiór przepisów dla placówek służby krwi. ed. Sabliński J, Łętowska M. Ministerstwo Zdrowia i Opieki Społecznej, Instytut Hematologii i Transfuzjologii, Warszawa 1996.

24. Lachert E, Woźniak J, Antoniewicz-Papis J, et al. Study of CD69 antigen expression and integrity of leukocyte cellular membrane in stored platelet concentrates following irradiation and treatment with Mirasol ${ }^{\circledR}$ PRT System. Adv Clin Exp Med. 2017; 26(1): 7-13, doi: 10.17219/ /acem/68290, indexed in Pubmed: 28397426.

25. Lachert E, Kubis J, Antoniewicz-Papis J, et al. Quality control of riboflavin-treated platelet concentrates using Mirasol® PRT system: Polish experience. Adv Clin Exp Med. 2018; 27(6): 765-772, doi: 10.17219/ /acem/68901, indexed in Pubmed: 29877637.

26. Lachert E, Antoniewicz-Papis J, Kubis J, et al. et al.. PRT Mirasol System - validation experience in Poland. J Transf Med. 2012; 5: 91-93.

27. Daszyński J, Maj S. Wpływ niskich temperatur na własności krwinek czerwonych. Pol Arch Med Wew. 1967; 39: 601-606.

28. Kotelba-Witkowska B, Skrzeczkowska E, Mrowiec Z. Przechowywanie koncentratów krwinek płytkowych w temperaturze $-80^{\circ} \mathrm{C}$. Ocena in vitro. Acta Haematol Pol. 1984; 15: 27-33.

29. Mrowiec Z, Skrzeczkowska E, Kotelba-Witkowska B, et al. Przechowywanie koncentratów krwinek płytkowych $w$ temperaturze $-80^{\circ} \mathrm{C}$. Ocena in vivo. Acta Haematol Pol. 1986; 17: 9-16.

30. Antoniewicz-Papis J, Lachert E, Rosiek A, et al. Otrzymywanie metodą automatyczną zlewanych koncentratów krwinek płytkowych. J Transf Med. 2010; 3: 49-54.

31. Rozporządzenie Ministra Zdrowia z dnia 11 września 2017 r. w sprawie warunków pobierania krwi od kandydatów na dawców krwi i dawców krwi (Dz.U. 2017 poz. 1741). http://isap.sejm.gov.pl/isap. nsf/DocDetails.xsp?id=WDU20170001741 (April 9, 2021).

32. Guide to the preparation, use and quality assurance of blood components. Recommendation No. R (95) 15. 20th Edition. European Directorate for the Quality of Medicines \& HealthCare (EDQM), Strasbourg 2020.

33. Sulkowska E, Kopacz A, Kubicka-Russel D, et al. Zastosowanie testu Syphilis Total Ab na aparacie Evolis (firmy BIO-RAD) do prowadzenia badań przeglądowych w krwiodawstwie. J Transf Med. 2017; 10(1): 1-11.

34. Grabarczyk P, Koppelman M, Boland F, et al. Inclusion of human immunodeficiency virus type 2 (HIV-2) in a multiplex transcription-mediated amplification assay does not affect detection of HIV-1 and hepatitis $B$ and $C$ virus genotypes: a multicenter performance evaluation study. Transfusion. 2015; 55(9): 2246-2255, doi: 10.1111/ /trf.13193, indexed in Pubmed: 26103564.
35. Kopacz A, Kubicka-Russel D, Liszewski G, et al. Charakterystyka testu cobas $₫$ MPX wraz z analizatorem cobas $₫ 6800$ oraz aparatem cobas p 680 (Roche) przeznaczonych do automatycznego badania dawców krwi w kierunku RNA wirusa zapalenia wątroby typu C (HCV), RNA ludzkiego wirusa nabytego niedoboru odporności (HIV) i DNA wirusa zapalenia wątroby typu B (HBV). J Transf Med. 2018; 11(2): 39-51.

36. Sulkowska E, Kubicka-Russel D, Zwolińska P, et al. And Polish Working Group On TTI. Hepatitis A virus in blood donations - epidemiology, virological characteristics and transfusion transmitted infections during epidemic; Poland, 2017-2019. Vox Sang. 2020; 115(Suppl. S1): P-431.

37. Grabarczyk P, Sulkowska E, Gdowska J, et al. Molecular and serological infection marker screening in blood donors indicates high endemicity of hepatitis E virus in Poland. Transfusion. 2018; 58(5): $1245-$ -1253, doi: 10.1111/trf.14531, indexed in Pubmed: 29492976.

38. Grabarczyk P. Transfusion-transmitted infections in Poland - trends, threats and prevention. Transfus Med Hemother. 2020; 47(Suppl 1): vS-13-1.

39. Sulkowska E, Kubicka-Russel D, Chrzanowska A, et al. HIV infection in Polish blood donors from 2005 to 2018 - trends in epidemiology and residual transfusion transmission risk. Vox Sang. 2020; 115(Suppl. S1): P-399.

40. Rozporządzenie Ministra Zdrowia w sprawie określenia rzadkich grup krwi, rodzajów osocza i surowic diagnostycznych, których uzyskanie wymaga przed pobraniem krwi lub jej składników wykonania zabiegu uodpornienia dawcy lub innych zabiegów, oraz wysokości rekompensaty (Dz. U. 2017, poz. 235). https://isap.sejm.gov.pl/isap.nsf/DocDetails.xsp?id=WDU20170000235 (April 9, 2021).

41. Guz K, Orzińska A, Michalewska B, et al. Molecular biology methods for blood cell antigen genotyping in reference laboratories. J Transfus Med. 2019; 12(4): 199-205, doi: 10.5603/jtm.2019.0010.

42. Orzińska A, Guz K, Michalewska B, et al. Molecular screening of the $C$ antigen for typing donors compatible with patients with anti-MAR-like antibodies. Blood Transfus. 2016; 14(6): 573-576, doi: 10.2450/2015.0044-15, indexed in Pubmed: 26509828.

43. Guz K, Orzińska A, Pelc-Kłopotowska M, et al. Identification of blood donors with rare red blood cell phenotypes using low-cost protocols. Vox Sang. 2018; 113(Suppl. 1): 263.

44. Obwieszczenie Ministra Zdrowia z dnia 17 lutego 2021 r. w sprawie ogłoszenia jednolitego tekstu rozporządzenia Ministra Zdrowia w sprawie leczenia krwią i jej składnikami w podmiotach leczniczych wykonujących działalność leczniczą w rodzaju stacjonarne i całodobowe świadczenia zdrowotne (Dz.U. 2021 poz. 504). http:// //isap.sejm.gov.pl/isap.nsf/DocDetails.xsp?id=WDU20210000504 (April 9, 2021).

45. Obwieszczenie Ministra Zdrowia z dnia 18 marca 2020 r. w sprawie wymagań dobrej praktyki przechowywania i wydawania krwi i jej składników dla banków krwi oraz badań z zakresu immunologii transfuzjologicznej wykonywanych w zakładach leczniczych podmiotów leczniczych innych niż regionalne centra, Wojskowe Centrum lub Centrum MSWiA (Dz.U. MZ. poz. 25, 2020). http://dziennikmz.mz.gov.pl/ /DUM_MZ/2020/25/akt.pdf (April 9, 2021).

46. Michalewska B, Wojciechowska B, Bednarz J, et al. Ocena funkcjonowania Pracowni Immunologii Transfuzjologicznej w Polsce. Acta Haematol Pol. 2017; 40(Suppl 1): 118.

47. Bednarz J, Pelc-Kłopotowska M, Wojciechowska B, et al. Assessment of the activities of Polish hospital transfusion laboratories based on surveys performed in 2015 and 2018. Vox Sang. 2020; 115(Suppl 1): 78. 
48. Pelc-Kłopotowska M, Wojciechowska B, Bednarz J, Sierpińska M, Guz K, Orzińska A, Michalewska B, Brojer E. Badania przedtransfuzyjne u pacjentów leczonych daratumumabem przy użyciu krwinek traktowanych DTT i DaraEx. Zeszyt Streszczeń XXVIII Zjazd Polskiego Towarzystwa Hematologów i Transfuzjologów Łódź, 12-14.09.2019.

49. Michalewska B, Żupańska B, Pelc-Kłopotowska M, et al. Alloimmunization in patients with autoimmune haemolytic anemia and genotyping of red blood cells to improve the selection of blood for transfusion]. J Transfus Med. 2009; 1: 14-19.

50. Pelc-Kłopotowska M, Guz K, Orzińska A, et al. Antibodies against high frequency antigen detected in patients between 2000 and 2017. Vox Sang. 2018; 113(Suppl. 1): 231.

51. Zupańska B, Brojer E, Richards Y, et al. Serological and immunological characteristics of maternal anti-Rh(D) antibodies in predicting the severity of haemolytic disease of the newborn. Vox Sang. 1989; 56(4): 247-253, doi: 10.1111/j.1423-0410.1989.tb02037.x, indexed in Pubmed: 2503936.

52. Żupańska B, Nowaczek-Migas M, Michalik M, et al. Whether all pregnant women should be screened for antibodies other than anti-D. Gin po Dypl. 2009; 2: 38-40.

53. Uhrynowska M, Niznikowska-Marks M, Zupańska B. Neonatal and maternal thrombocytopenia: incidence and immune background. Eur J Haematol. 2000; 64(1): 42-46, doi: 10.1034/j.16000609.2000.09007.x, indexed in Pubmed: 10680704.

54. Dębska M, Uhrynowska M, Guz K, et al. Identification and follow-up of pregnant women with platelet-type human platelet antigen (HPA)-1bb alloimmunized with fetal HPA-1a. Arch Med Sci. 2018; 14(5): 1041-1047, doi: 10.5114/aoms.2016.63600, indexed in Pubmed: 30154886.

55. Uhrynowska M, Guz K, Orzińska A, et al. Results of HPA-1a screening program for identification of pregnant women at risk of foetal/neonatal alloimmune thrombocytopenia (FNAIT). Vox Sang. 2019; 114(Suppl.1): 59.

56. Orzińska A, Guz K, Uhrynowska M, et al. Noninvasive prenatal HPA-1 typing in HPA-1a negative pregnancies selected in the Polish PREVFNAIT screening program. Transfusion. 2018; 58(11): 2705-2711, doi: 10.1111/trf.14963, indexed in Pubmed: 30260485.

57. Kotelba-Witkowska B, Zupańska B, Brojer E, et al. Predictive value of lymphocytotoxic test and platelet aggregometry for the effect of transfused platelet concentrates. Haematologia (Budap). 1981; 14(4): 375-381, indexed in Pubmed: 7344974.

58. Maślanka K, Guz K, Uhrynowska M, et al. [Registry of blood donors typed for human platelet antigens (HPA) and its application in platelet transfusion]. Acta Haematol Pol. 2005; 36: 189-196.

59. Guz K, Łopacz P, Gierszon A, et al. Availability of the platelet concentrates for immunized patients from donors with HLA and/or HPA typed antigens. J Transfus Med. 2019; 12: 1-12.

60. Zupańska B, Uhrynowska M, Konopka L. Transfusion-related acute lung injury due to granulocyte-agglutinating antibody in a patient with paroxysmal nocturnal hemoglobinuria. Transfusion. 1999; 39(9): 944-947, doi: 10.1046/j.1537-2995.1999.39090944.x, indexed in Pubmed: 10533819.

61. Maślanka K, Michur H, Zupańska B, et al. Leucocyte antibodies in blood donors and a look back on recipients of their blood components. Vox Sang. 2007; 92(3): 247-249, doi: 10.1111/j.14230410.2007.00890.x, indexed in Pubmed: 17348874.

62. Maślanka K, Uhrynowska M, Łopacz P, et al. Analysis of leucocyte antibodies, cytokines, lysophospholipids and cell microparticles in blood components implicated in post-transfusion reactions with dyspnoea. Vox Sang. 2015; 108(1): 27-36, doi: 10.1111/vox.12190, indexed in Pubmed: 25134637.
63. TRALI i prawdopodobne TRALI zdiagnozowane w Polsce w okresie styczeń 2014 - marzec 2019; analiza wyników badań laboratoryjnych. Zeszyt Streszczeń, str 50. XXVIII Zjazd Polskiego Towarzystwa Hematologów i Transfuzjologów. Łódź, 12-14.09.2019.

64. Drzewek K, Brojer E, Zupańska B. The frequency of human platelet antigen (HPA) genotypes in the Polish population. Transfus Med. 1998; 8(4): 339-342, doi: 10.1046/j.1365-3148.1998.00164.x, indexed in Pubmed: 9881429.

65. Guz K, Brojer E, Zupańska B. Implications of NA1/NA2 and SH genotyping results in the Polish population with regard to the new nomenclature of granulocyte alloantigens. Transfusion. 2000; 40(4): 490-1; author reply 492, doi: 10.1046/j.1537-2995.2000.40040490.x, indexed in Pubmed: 10773063.

66. Orzińska A, Guz K, Polin H, et al. RHD variants in Polish blood donors routinely typed as D-. Transfusion. 2013; 53(11 Suppl 2): 2945-2953, doi: 10.1111/trf.12230, indexed in Pubmed: 23634715.

67. Pelc-Kłopotowska M, Guz K, Orzińska A, et al. Evaluation of reactivity of various monoclonal anti-D reagents with red blood cells of individuals with inconclusive RhD results. Vox Sang. 2020; 115(Suppl.1): 256.

68. Michalewska B, Olsson ML, Naremska G, et al. FUT1 mutations responsible for the H-deficient phenotype in the Polish population, including the first example of an abolished start codon. Blood Transfus. 2018; 16(1): 101-104, doi: 10.2450/2016.0135-16, indexed in Pubmed: 27893357.

69. Polin H, Pelc-Klopotowska M, Danzer M, et al. Compound heterozygosity of two novel RHAG alleles leads to a considerable disruption of the Rh complex. Transfusion. 2016; 56(4): 950-955, doi: 10.1111/ /trf.13476, indexed in Pubmed: 27079312.

70. Guz K, Pelc-Kłopotowska M, Purchla-Szepioła S, et al. A novel ABO*A allele with 21 base pair duplication in Polish individuals. Transfusion. 2020; 60(11): E48-E50, doi: 10.1111/trf.16085, indexed in Pubmed: 32945531.

71. Orzińska A, Guz K, Dębska M, et al. 14 years of Polish experience in non-invasive prenatal blood group diagnosis. Transfus Med Hemother. 2015; 42(6): 361-364, doi: 10.1159/000440821, indexed in Pubmed: 26733766.

72. Orzińska A, Guz K, Purchla-Szepioła S, et al. 3-year experimenst in non-invasive prenatal testing of fetal RHD for targeted anti-D immunoprophylaxis in Poland. Vox Sang. 2019; 114(Suppl 1): 201.

73. Orzińska A, Guz K, Mikula M, et al. Prediction of fetal blood group and platelet antigens from maternal plasma using next-generation sequencing. Transfusion. 2019; 59(3): 1102-1107, doi: 10.1111/ /trf.15116, indexed in Pubmed: 30620409.

74. Stachurska A, Król T, Trybus W, et al. 3D visualization and quantitative analysis of human erythrocyte phagocytosis. Cell Biol Int. 2016; 40(11): 1195-1203, doi: 10.1002/cbin.10671, indexed in Pubmed: 27569596.

75. Fabijańska-Mitek J, Stachurska A. Zastosowanie cytometrii przepływowej w badaniach immunohematologicznych krwinek czerwonych. Acta Haematol Pol. 2017; 48(3): 183-188, doi: 10.1016/j.achaem.2017.07.005.

76. Stachurska A, Dorman M, Korsak J, et al. Selected CD molecules and the phagocytosis of microvesicles released from erythrocytes ex vivo. Vox Sang. 2019; 114(6): 576-587, doi: 10.1111/vox.12819, indexed in Pubmed: 31281973.

77. Lachert E, Antoniewicz-Papis J, Kubis J, et al. Klej fibrynowy. Blok Operacyjny. 2002; 2: 80-83. 
78. Antoniewicz-Papis J, Lachert E, Janik K, et al. Autologous artificial tears used for treatment of dry eye syndrome in patients with chronic graft versus host disease. Pol Arch Intern Med. 2017; 127(10): 705-707, doi: 10.20452/pamw.4127, indexed in Pubmed: 29162791.

79. Wunsch E, Kruk B, Snarski E, et al. Plasmapheresis in the treatment of chronic fatigue in patients with primary biliary cholangitis. Pol Arch Intern Med. 2021; 131(2): 205-207, doi: 10.20452/pamw.15690, indexed in Pubmed: 33236867.

80. Padmanabhan A, Connelly-Smith L, Aqui N, et al. Guidelines on the use of therapeutic apheresis in clinical practice - evidence-based approach from the Writing Committee of the American Society for Apheresis: The Eighth Special Issue. J Clin Apher. 2019; 34(3): 171-354, doi: 10.1002/jca.21705, indexed in Pubmed: 31180581.

81. Nowak J, Gronkowska A, Brojer E. Strategy of marrow donor search among family members for the patients who do not have a matched sibling. Acta Haematol Pol. 2002; 33: 309-316.

82. Nowak J. Matching and recruitment of unrelated bone marrow donors in Poland. Acta Haematol Pol. 2002; 33: 417-430.

83. Nestorowicz K, Łęczycka A, Dudkiewicz M. Centralny Rejestr Niespokrewnionych Potencjalnych Dawców Szpiku i Krwi Pępowinowej (CRNPDSiKP). Poltransplant Biuletyn Informacyjny. 2020; 29: 61-69.

84. Nowak J, Nestorowicz K, Graczyk-Pol E, et al. HLA-inferred extended haplotype disparity level is more relevant than the level of HLA mismatch alone for the patients survival and GvHD in T cell-replate hema- topoietic stem cell transplantation from unrelated donor. Hum Immunol. 2018; 79(6): 403-412, doi: 10.1016/j.humimm.2018.03.011, indexed in Pubmed: 29605688.

85. Graczyk-Pol E, Rogatko-Koros M, Nestorowicz K, et al. Role of donor HLA class I mismatch, KIR-ligand mismatch and HLA:KIR pairings in hematological malignancy relapse after unrelated hematopoietic stem cell transplantation. HLA. 2018; 92 Suppl 2: 42-46, doi: 10.1111/ /tan.13386, indexed in Pubmed: 30168290.

86. Nowak J, Kościńska K, Mika-Witkowska R, et al. Polish Donor-Recipient Matching Study Group. Donor NK cell licensing in control of malignancy in hematopoietic stem cell transplant recipients. Am J Hematol. 2014; 89(10): E176-E183, doi: 10.1002/ajh.23802, indexed in Pubmed: 25044365.

87. Poszwiński P, Węgrzecki T, Seyfried H, et al. Produkcja immunoglobuliny anty-D. Pol Tyg Lek. 1974; 29: 823-825.

88. Seyfried H, Poszwiński P, Frankowska K, et al. Czteroletnie doświadczenie $w$ dziedzinie produkcji i stosowania immunoglobuliny anty-RhD. 1. Produkcja preparatów gamma anty-D. Ginekol Pol. 1978; 49: 743-746.

89. Poszwiński P, Kacperska E, Głoskowska-Moraczewska Z, et al. Immunoglobulina anty-HBs. Pol Tyg Lek. 1979; 34(46): 1789-1791.

90. Standard Pracy Komitetu Transfuzjologicznego. ed. Pogłód R, Antoniewicz-Papis J. Wydanie II. Instytut Hematologii i Transfuzjologii, Warszawa 2020. 